\title{
KONSEP JILBAB DAN IDENTITAS KEAGAMAAN PERSEPSI MAHASISWI SEBAGAI CALON GURU PAI
}

\section{Layli Tsurayya}

Alumni Pascasarjana UIN Sunan Kalijaga Yogyakarta

Jl. Laksda Adisucipto, Caturtunggal, Kecamatan Depok, Kabupaten

Sleman, Daerah Istimewa Yogyakarta 55281.

laylitsurayya@gmail.com

\section{Muhamad Agus Mushodiq}

Dosen pada Institut Agama Islam Ma'arif NU (IAIM NU) Kota Metro

Lampung

Jl. RA. Kartini 28 Purwosari Metro Utara Kota Metro Lampung agusmushodiq92@gmail.com

\begin{tabular}{|c|c|c|}
\hline Diterima: & Revisi: & Disetujui: \\
25 September 2018 & 20 Oktober 2018 & 11 Desember 2018 \\
\hline
\end{tabular}

\begin{abstract}
In the tradition of the religious expression of Islam, one of which can be seen through the veil. In Indonesia, the phenomenon of women veiled growing along with the development of the diversity of models and variations of the hijab. In connection with the phenomenon, the authors of driven to do research among academics, headscarves, namely Faculty of Tarbiyah PIE Coed and teacher training UIN Sunan Kalijaga Yogyakarta, which notabenenya as a potential teacher PAI. This type of research is a research field that is descriptive-qualitative. The technique in the determination of the subject of the research that the author use is observation, in-depth interviews and documentation involved, while the analysis of the data using a descriptive-analytic, and ultimately the conclusion. By using the theory of the Glock and Stark, the results showed: first, understanding of the concept of hijab according to female student of PAI as religion teacher candidates not only have a single concept, but rather is composed of five variations, namely: (1) Hijab as an obligation in Islam to cover nakedness, (2) Hijab as Muslim identity, (3) Hijab as motivation to form characters, (4) Hijab protectors, 5) the
\end{abstract}


hijab as a form of homage to the women, and (6) Hijab as a Muslim woman's new life style. Second, the influence of the concept of the hijab Coed PAI against religious behavior can be seen from two competence, i.e. of the personality and social.

Key Word: hijab, female student, competence, islamic studies

\begin{abstract}
Abstrak
Dalam tradisi Islam, ekspresi keagamaan tersebut salah satunya dapat dilihat melalui jilbab. Di Indonesia, fenomena wanita berjilbab semakin meningkat seiring dengan perkembangan keanekaragaman model dan variasi jilbab. Sehubungan dengan fenomena tersebut, penulis terdorong untuk melakukan penelitian jilbab di kalangan akademisi, yaitu Mahasiswi PAI Fakultas Ilmu Tarbiyah dan Keguruan UIN Sunan Kalijaga Yogyakarta yang notabenenya sebagai calon guru PAI. Jenis penelitian ini adalah penelitian lapangan yang bersifat deskriptifkualitatif. Teknik dalam penentuan subjek penelitian yang penulis gunakan adalah wawancara mendalam, observasi terlibat dan dokumentasi, sedangkan analisis datanya menggunakan deskriptifanalitik, dan pada akhirnya kesimpulan. Dengan menggunakan teori Glock dan Stark, penelitian ini menunjukkan hasil: Pertama, konsep pemahaman tentang jilbab menurut Mahasiswi PAI sebagai calon guru agama tidak hanya memiliki konsep tunggal, melainkan terdiri dari lima variasi, yaitu: (1) Jilbab sebagai kewajiban dalam Islam untuk menutup aurat, (2) Jilbab sebagai identitas muslimah, (3) Jilbab sebagai motivasi untuk membentuk karakter, (4) Jilbab sebagai pelindung, 5) Jilbab sebagai bentuk penghormatan kepada kaum wanita, dan (6) Jilbab sebagai gaya hidup baru wanita muslimah. Kedua, Pengaruh konsep jilbab Mahasiswi PAI terhadap perilaku keagamaannya dapat dilihat dari dua kompetensi, yakni dari kepribadian dan sosial.
\end{abstract}

Kata Kunci: Jilbab, Mahasiswi, kompetensi, Pendidikan Agama Islam

\title{
A. Pendahuluan
}

Globalisasi mempengaruhi perilaku keagamaan atau ekspresi keagamaan umat Islam. Perilaku keagamaan dalam Islam bisa dilihat dari banyak hal, seperti halnya dalam berpakaian. Dalam tradisi Islam, pakaian yang melukiskan keberagamaan seorang wanita adalah 
melalui jilbab. ${ }^{1}$ Jilbab yang sejatinya berfungsi sebagai penutup aurat wanita kini cenderung dipergunakan sebagai trend center dunia fashion. Pemakaian jilbab yang sedang ramai ini didukung oleh semakin banyaknya keragaman bentuk dan model jilbab sehingga banyak remaja muslim Indonesia yang memakainya dengan maksud mempercantik diri. Mereka berlomba-lomba dalam memadupadankan antara pemakaian jilbab dengan busana yang dikenakan.

Perubahan sosial yang terjadi ini ikut mempengaruhi pemaknaan jilbab bagi setiap pemakainya. Jilbab yang dimaknai sebagai simbol agama atau identitas keberagamaan seorang wanita ini memiliki peran positif pada diri pemakainya secara psikologis. Senada dengan hal itu, sebagaimana dikutip dari buku Quraish Shihab, Kefgen dan Touchhie-Speche berargumen bahwa jilbab memiliki tiga fungsi, ketiganya adalah diferensiasi, perilaku, dan emosi. Fungsi diferensiasi yang dimaksud adalah jilbab dapat membedakan dirinya dengan kelompok lain serta memberikan identitas keislaman. Begitu juga dengan fungsi jilbab sebagai perilaku, pemakaian jilbab mempengaruhi pemakainya untuk berperilaku sesuai dengan citra diri seorang muslimah. Adapun jika digunakan secara massal oleh suatu kelompok, maka jilbab dapat mendorong emosi keagamaan kelompok tersebut. ${ }^{2}$ Sejalan dengan pendapat tersebut, dalam penerapannya, salah satu mahasiswi PAI UIN Sunan Kalijaga Angkatan 2013 berpendapat bahwa, "Jilbab itu bukan suatu kewajiban yang mengekang, namun itulah pakaian yang baik buat seorang wanita, kalau kita menggunakan jilbab kita akan lebih tercover, tercover dari hati maupun dari luar. Jilbab itu seperti ada motivasi tersendiri untuk merubah karakter kita dan karakter itu menyesuaikan seperti apa yang saya pakai."3

1 Hasil penelitian yang dilakukan oleh Anwar Musaddad, "Hubungan antara Jilbab dengan Perilaku Islami", Jurusan Komunikasi dan Penyiaran Islam Fakultas Dakwah dan Komunikasi Universitas Islam Negeri Hidayatullah, Jakarta. 2008

2 M. Quraish Shihab, Jilbab, Pakaian Wanita Muslimah: Pandangan Ulama Masa lalu dan cendekiawan kontemporer, (Jakarta:Lentera Hati, 2004), h. 34

3 Hasil wawancara dengan informan 0 pada hari Kamis, tanggal 14 April 2016 pukul 12.30 di lantai 1 Fakultas Syari"ah 
Di dalam konteks sejarahnya, jilbab digunakan oleh wanita untuk melindungi diri dari gangguan laki-laki yang tidak memiliki sopan santun dan untuk membedakan antara dirinya sebagai wanita yang merdeka dengan wanita budak. Terutama ketika Islam berkuasa dan berjaya menguasai dunia pada masa kerajaan Utsmaniyah, banyak orang-orang Barat yang mengikuti gaya berjilbab wanita muslimah, yakni lebar, panjang, dan bercadar. Sebagaimana yang dipraktikkan oleh Ratu Austria yang mengenakan cadar dan pakaian panjang di tengah-tengah rakyatnya yang notabene non-muslim. ${ }^{4}$

Data-data di atas diperkuat oleh hasil temuan peneliti bernama Fadwa El Guindi yang telah melakukan observasi langsung seputar masalah jilbab. Penelitiannya tersebut dilakukan selama 30 bulan riset lapangan dan 12 tahun observasi yang berada di wilayah lembah Zapotec Oaxaca. Menurutnya, jilbab menunjukkan kedewasaan dan identitas kehormatan wanita. Di Indonesia sendiri istilah jilbab telah dipopulerkan oleh ibu Fatmawati, istri presiden pertama Indonesia. Dalam hal ini ibu Fatmawati seakan hendak menunjukkan pada dunia bahwa apa yang dipakainya saat itu merupakan pakaian khas Indonesia. ${ }^{5}$ Jadi, ketika itu jilbab lebih kental menjadi simbol identitas kebangsaan. Dari paparan di atas dapat disimpulkan bahwa jilbab merupakan lambang ketinggian derajat, kemuliaan dan kemerdekaan kaum wanita.

Namun, fenomena belakangan ini yang terjadi adalah jilbab yang seharusnya merupakan tanda kemuliaan wanita mengalami pergeseran makna. Pergeseran makna tersebut disebabkan oleh adanya motivasi lain dalam pemakaian jilbab yang tidak berdasarkan syariat Islam, yang dikenal dengan istilah Jilboobs. Jilboobs adalah sebutan untuk menyindir wanita yang mengenakan jilbab namun masih menampakkan bentuk lekuk tubuhnya. Pemakai jilboobs

4 http://akhwat.beritaislamterbaru.org/2016/01/ketika-islam-berkuasacadar-justru.html diakses pada hari Kamis, 26 Mei 2016 pukul 05.17

${ }^{5}$ Fathonah K.Daud, "Jilbab, Hijab dan Aurat Perempuan (Antara Tafsir Klasik, Tafsir Kontemporer dan Pandangan Muslim Feminis)" Jurnal Studi KeIslaman, Volume 3, Nomor 1, Maret 2013, h. 1 
biasanya menggunakan jilbab yang pendek dengan baju atasan atau celana yang ketat, memakai leging dan baju yang transparan. ${ }^{6}$ Menurut Hannie Hananto sebagai desainer busana muslim, istilah jilboobs pada mulanya merupakan sindiran untuk wanita yang memiliki tingkat pengetahuan dan pemahaman yang rendah mengenai mengenai aturan jilbab dalam Islam. ${ }^{7}$ Fenomena ini menunjukkan bahwa berjilbab saja tidaklah cukup. Jilbab yang seharusnya menunjukkan kedudukan wanita yang terhormat mengalami pergeseran makna di sebagian masyarakat. Hal ini tidak sesuai dengan esensi jilbab itu sendiri seperti yang sudah peneliti kemukakan di atas. Jilbab merupakan kain yang diperuntukkan untuk wanita muslimah berfungsi untuk menutupi auratnya dengan baik. Seperti penuturan dari salah satu mahasiswi yang memahami bahwa jilbab yang selayaknya dipakai wanita muslimah, "Jilbab yang saya pahami itu sampai menutupi dada, tidak menampilkan lekuk tubuh seorang wanita. Dapat melindungi kita dari godaan laki-laki dan tidak mengundang laki-laki untuk tergoda dengan kita."8

Perilaku keberagamaan yang tercermin dalam jilbab menjadi poin menarik terlebih jika dikaitkan dengan calon guru agama, khususnya Mahasiswi PAI di Fakultas Tarbiyah. Hal ini bertujuan untuk membantu dan membiasakan mahasiswi yang notabenenya sebagai calon guru Agama Islam menjadi berkarakter karena kelak menjadi model bagi peserta didik. Seorang guru Agama Islam dipandang oleh sebagian masyarakat sebagai tolak ukur keberhasilan akhlak peserta didik. Terlebih dengan banyaknya kasus dan perilaku kriminal yang sebagian besar menimpa pelajar di bawah umur, seperti pelecehan seksual, pemerkosaan anak-anak dan lebih sadisnya adalah

6 Pratomo, Yulistyo (7 Agustus 2014). "'Istilah Jilboobs penghinaan bagi perempuan berjilbab'". Merdeka.com. Diakses pada hari Selasa, tanggal 24 Mei 2016 pukul 13.00 .

7 http://www.kompasiana.com/kompasiana/jilboobs-antara metamorfosisesensi-jilbab-fenomena-tapi-bukan-tren-fashionmuslim_54f5d9f0a33311424f8 b472e diakses pada hari Rabu, tanggal 25 Mei 2016 pukul 05.25

8 Hasil wawancara dengan informan H pada hari Sabtu 12 April 2016 pukul 09.00 di masjid kampus UIN Sunan Kalijaga 
dibarengi dengan kasus pembunuhan. Oleh karena itu, maka diperlukan seorang guru yang menampilkan model dengan karakter tertentu, dalam hal ini adalah dari pembiasaan jilbab yang tepat sesuai syariat. Meskipun tidak dapat menjamin menumpas seluruh kasus tersebut, namun melalui berpakaian yang baik, berhati-hati dalam segala tindakan dan tidak menggoda lawan jenis dapat diajarkan kepada peserta didik sebagai pelindung bagi keselamatan mereka.

Berkaitan dengan penelitian yang dilakukan, kajian ini memfokuskan pada perilaku keagamaan mahasiswi yang tercermin dalam berjilbab dengan subjek penelitiannya adalah Mahasiswi Jurusan Pendidikan Agama Islam UIN Sunan Kalijaga Angkatan 2013 sebanyak 20 orang. Adapun teori yang digunakan dalam penelitian ini adalah teori Glock \& Stark, yakni dimensi-dimensi keberagamaan. menurut kedua tokoh tersebut, terdapat lila dimensi keberagamaan pada diri seseorang, yaitu: dimensi keyakinan, dimensi pengetahuan agama, dimensi praktik agama atau ritual keagamaan, dimensi pengalaman, dan dimensi pengamalan agama.

Dengan menggunakan kelima dimensi keagamaan tersebut, maka akan membantu peneliti untuk mengetahui seperti apa keyakinan agama mahasiswi, bagaimana relasinya dengan sesama manusia dan Tuhannya serta untuk mengetahui dampak dari perubahan-perubahan yang terjadi. Bermula dari dimensi keyakinan yang berisi tentang harapan seseorang terhadap agama yang dianutnya dengan jalan meyakini, mengakui dan mengikuti kebenaran dari ajaran agamanya, kemudian dimensi praktik menunjukkan pada kepatuhan umat muslim dalam menjalankan kegiatan-kegiatan ritual sebagaimana disuruh dan dianjurkan agamanya. Setelah mempraktikkan kepatuhan yang diyakininya, maka seseorang tersebut akan memiliki pengalaman tersendiri yang masuk dalam jiwanya, kemudian setelah itu memperoleh pengetahuan tentang agama yang diyakininya, pengetahuan yang semakin lama semakin berkembang, dan pada akhirnya komitmen dengan agama yang dianutnya yang mengacu pada identifikasi akibat-akibat keyakinan keagamaan, praktik pengalaman dan pengetahuan seseorang dari hari ke hari. 


\section{B. Dimensi Keberagamaan Glock dan Stark}

Glock dan Stark dua tokoh psikologi yang terkemuka, mengatakan bahwa ada lima macam dimensi keberagamaan sebagai indikator untuk mengetahui keberagamaan seseorang, yaitu (1) Dimensi keyakinan (Ideologi) yang berisi pengharapan-pengharapan di mana religiusitas berpegang teguh pada pandangan teologis tertentu dan mengakui kebenaran-kebenaran. Keyakinan atau dalam istilah yang dipakai oleh Djamaludin Ancok adalah akidah Islam, pada dasarnya sudah tertanam sejak manusia ada dalam alam azali (prakelahiran). Akidah akan terpelihara dengan baik apabila perjalanan hidup seseorang diwarnai dengan penanaman tauhid yang memadai. ${ }^{9}$ Menurut Maududi, dasar segala bentuk ketaatan dan kepatuhan di dalam Islam adalah iman. ${ }^{10}$

Dimensi keyakinan dalam penelitian ini adalah tentang keyakinan mahasiswi terhadap anjuran berjilbab dalam Islam. Unsur keyakinan dalam diri mahasiswi menjadi landasan tentang pengamalannya dalam kehidupan sehari-hari. Ketika seseorang meyakini bahwa jilbab itu indah, baik dan bermanfaat maka ia akan semakin mendalami lagi pengetahuan tentang jilbab dan hal-hal yang terkait dengan makna jilbab dalam ajaran Islam. ciri-ciri dari ideologi atau keyakinan itu sendiri adalah taat dan patuh terhadap perintah Tuhan, taqwa; menjalankan semua kewajiban yang diperintahkan Tuhan dan meninggalkan yang dilarang oleh Tuhan., dan meyakini semua apa yang sudah diperintahkan oleh Tuhan adalah yang terbaik untuk kehidupan manusia, (2) dimensi pengetahuan agama (Intelektual) yang berkaitan dengan pengetahuan tentang ajaran agama yang dianut dan diyakininya. Seseorang yang beragama baik pada dasarnya telah mengetahui berbagai ilmu atau pengetahuan yang mendalam mengenai agama yang diyakininya tersebut. Adapun ciri dari pengetahuan agama mahasiswi terhadap jilbab tersebut

9 Djamaludin Ancok, Fuat Nashori Suroso, Psikologi Islam.(Jakarta: Pustaka Pelajar, 2011) h. 81

10 Husein Shahab, Hijab menurut al-Qur'an dan al-Sunah: Pandangan Muthahhari dan al-Maududi, (Bandung: Mizan, 2013), h. 2 
adalah mengetahui landasan dan hukum berjilbab, mengetahui tujuan berjilbab, mengetahui dampak positif berjilbab terhadap perilaku keagamaannya, dan mengetahui konsekuensi berjilbab dalam kesehariannya.

Tingkat pengetahuan seseorang dalam memahami ajaran agamanya dipengaruhi oleh faktor usia. Luella Cole, seorang psikolog pakar masalah remaja, mengajukan pembagian masa remaja sebagai berikut: Preadolescence atau pra-remaja terjadi pada usia 11-13 thn (pr); 13-15 thn (lk), Early adolescemce atau remaja pemula terjadi pada usia 13-15 thn (pr); 15-17 thn (lk), Middle adolescence atau remaja madya pada usia15-18 thn (pr)); 17-19 thn (lk) dan Late adolescence atau remaja akhir pada usia 18-21 thn (pr); 19-21 thn (lk). ${ }^{11}$ Dalam The Development of Religious on Children, Ernest Harms mengungkapkan bahwa perkembangan agama pada anak-anak ditentukan oleh tingkat usia mereka. Perkembangan tersebut pula oleh perkembangan berbagai aspek kejiwaan, termasuk perkembangan berpikir.12 Perubahan dan perkembangan yang berlangsung tidak hanya terjadi pada aspek ragawi, tetapi juga dalam kemampuan berpikir, alam perasaan, arah minat, sikap, lingkungan pergaulan, rasa keagamaan, dan sebagainya, yang semuanya adalah perkembangan kepribadian secara menyeluruh meliputi dimensidimensi ragawi, kejiwaaan, kemasyarakatan dan keruhanian, (3) Dimensi Praktik (Agama Ritual) yang mencakup pada semua perilaku ritual keagamaan atau pemujaan, ketaatan dan hal-hal yang dilakukan untuk menunjukkan komitmen dan ketaatan terhadap agama yang dianut dan diyakininya. Perilaku keagamaan merupakan suatu tingkah laku manusia yang berhubungan dengan keyakinan agama yang dianutnya. Dimensi praktik keagamaan dalam penelitian ini adalah praktik keagamaan atau ekspresi keagamaan mahasiswi dalam

11 Luella Cole, Psychology of Adolescence. Holt Rinebart and Winston,(New York, 1953), dikutip dari buku Hanna Bastaman, Integrasi Psikologi dengan Islam: Menuju Psikologi Islami, (Yogyakarta: Pustaka Pelajar, 1997), h.. 16538 Bambang Syamsul Arifin, Psikologi Agama, (Bandung: Pustaka Setia, 2015), h.. 80

12 Bambang Syamsul Arifin, Psikologi Agama, (Bandung: Pustaka Setia, 2015), h. 80 
berjilbab. Sebagai calon guru Agama Islam, praktik berjilbab sangat penting terkait profesi mereka. Jilbab identik dengan ajaran Islam yang melambangkan kemuslimahan seseorang. Ciri-ciri dari dimensi praktik ini adalah memakai jilbab dengan tidak menampakkan lekuk tubuhnya, memakai jilbab sampai menutupi dada, tidak memakai jilbab yang transparan, dan tidak berlebih-lebihan dalam memakai jilbab, seperti terlalu pendek dan terlalu panjang, (4) dimensi pengalaman/penghayatan (Experience) yang berisi fakta bahwa semua agama mengandung pengharapan-pengharapan tertentu, meski tidak tepat jika dikatakan bahwa seseorang yang beragama dengan baik pada suatu saat akan mencapai pengetahuan subyektif dan langsung mengenai akhir (kenyataan terakhir bahwa ia akan mencapai suatu kontak dengan kekuatan supranatural). Mengenai penghayatan dan pemahaman keagamaan, G.W. Allport menyatakan bahwa pada umumnya para remaja menunjukkan perubahan sikap terhadap agama.13 dan (5) dimensi pengamalan (Consequential) Dimensi dengan komitmen agama yang dianut seseorang yang mengacu pada identifikasi akibat-akibat keyakinan keagamaan, praktik pengalaman dan pengetahuan seseorang dari hari ke hari.

\section{Hasil Penelitian dan Pembahasan}

1. Konsep Jilbab Mahasiswi PAI

a) Dimensi Keyakinan Berjilbab Mahasiswi

Dimensi keyakinan agama ini berisi mengenai pengharapan-pengharapan yang ada dalam diri mahasiswi PAI dan mengakui kebenaran-kebenaran dari ajaran agama Islam mengenai anjuran berjilbab. Pada dimensi ini, para mahasiswi meyakini bahwa Islam merupakan agama yang mulia, memiliki ajaran yang baik, dan sebagai rahmat bagi umat manusia. Mereka juga meyakini bahwa jilbab merupakan pakaian terbaik bagi seorang wanita muslimah. Di samping

13 Gordon W. Allport, The Individual and His Religion, The Macmillan Company; 1962. 32-36. dikutip dari buku Hanna Bastaman, Integrasi Psikologi dengan Islam: Menuju Psikologi Islami, (Yogyakarta: Pustaka Pelajar, 1997), h.. 165 
memberikan nuansa kesejukan dan keanggunan bagi orang yang memandang, jilbab juga akan memberikan nilai kehormatan kepada seorang wanita.

Dari hasil wawancara dengan 20 mahasiswi, dapat disimpulkan bahwa keyakinan mahasiswi PAI UIN Sunan Kalijaga tentang anjuran berjilbab dalam Islam sudah tergolong baik. Keyakinan atau akidah Islam yang dimiliki oleh mahasiswi, pada dasarnya sudah tertanam sejak mereka ada dalam alam azali (pra-kelahiran). Akidah mereka akan terpelihara dengan baik apabila perjalanan hidupnya diwarnai dengan penanaman tauhid yang memadai. Penanaman tauhid tersebut dapat berasal dari lingkungan keluarga yang merupakan lingkungan terdekat, kemudian lingkungan sekolah dan lingkungan sosialnya. Dengan memiliki informasi yang benar yang berlandaskan Alquran dan as-Sunnah, maka janji manusia untuk mengakui kekuasaan Tuhan akan terpelihara.

\section{b) Dimensi Pengetahuan Agama Mahasiswi Tentang Jilbab}

Pengetahuan agama mahasiswi PAI tentang jilbab ini tumbuh dan berkembang melalui berbagai proses, di antaranya seperti proses interaksi dengan anggota keluarga, interaksi dengan tokoh-tokoh intelektual, interaksi dengan masyarakat sekitar, dan interaksi dengan lingkungan sekolahnya. Pengetahuannya tersebut akan mendorong mahasiswi meyakini agamanya dengan sepenuh hatinya dan mengembangkan pengetahuannya agar selalu berperilaku sesuai dengan apa yang sudah diperoleh.

Dari penilaian dimensi pengetahuan mahasiswi tentang jilbab, dapat ditarik kesimpulan bahwa mahasiswi PAI UIN Sunan Kalijaga mempunyai pengetahuan agama yang cukup luas dan bervariasi mengenai jilbab, baik dilihat dari segi makna dan tujuannya. Pemahaman mahasiswi terkait pengetahuan agama dan jilbab relatif sama. Hal ini karena 
penjelasan mereka sesuai dengan penjelasan dalam ajaran Islam. Dengan memiliki pengetahuan agama yang baik tentang jilbab dalam Islam, maka keyakinan mahasiswi terhadap hukum-hukum Allah dan kekuasaan Allah akan menjadi semakin kuat. ${ }^{14}$ Pengembangan pengetahuan ditentukan oleh beberapa faktor, dan faktor tersebut yang membedakan tingkat pemahaman mahasiswi yang satu dengan yang lainnya. Adapun yang membedakan tinggi rendahnya pengetahuan mereka adalah adanya faktor internal yang meliputi kondisi emosional mahasiswi atau motivasi yang melatarbelakangi dan perkembangan usianya, dan faktor eksternal berupa pengaruh luar yang dialaminya.

Pertama, faktor internal. Perkembangan usia dan perkembangan jiwa keagamaan mahasiswi tidak dapat dihilangkan begitu saja. Meskipun tingkat usia bukan merupakan satu-satunya faktor penentu dalam perkembangan jiwa keagamaan seseorang. Dari hasil wawancara sejumlah 20 mahasiswi, didapatkan hasil: sebanyak 15 orang mahasiswi berada pada usia 20 tahun, 4 orang mahasiswi berada pada usia 21 tahun, dan 1 orang mahasiswi berada pada usia 22 tahun.

Kedua, faktor eksternal. Sebagai makhluk ciptaan Tuhan, sebenarnya potensi agama sudah ada pada setiap manusia sejak dilahirkan. Pembinaan nilai-nilai agama oleh kedua orangtua di dalam keluarga menjadi faktor bagaimana dorongan keberagamaan seorang anak tersebut apakah menjadi penganut yang taat ataukah biasa saja. Adapun yang termasuk faktor eksternal di sini adalah meliputi keluarga, sekolah dan masyarakat.

Berdasarkan hasil wawancara dengan mahasiswi terkait konsep pemahaman jilbab di atas, mereka sama-sama

14 Zakiah Daradjat, Pendidikan dan Kesehatan Mental, (Jakarta: Bulan Bintang, 1976), hlm. 57 
berpendapat bahwa jilbab adalah suatu kewajiban bagi wanita, tidak hanya itu, mereka juga berpendapat bahwa jilbab sebagai identitas wanita muslimah. Bangunan pengetahuan yang mereka dapatkan berlandaskan syariat Islam ini didasari oleh peran pendidikan di dalam keluarga, kemudian belajarmengajar di lingkungan sekolah, tidak hanya pendidikan formal namun juga nonformal, seperti TPA atau madrasah kelas sore. Melalui tahap-tahap tersebut maka mahasiswi mendapatkan pengetahuan yang lebih luas mengenai jilbab, kemudian mereka mengembangkan pengetahuannya ke dalam lingkungan sosial melalui proses sosialisasi.

2. Pengaruh Jilbab terhadap Perilaku Mahasiswi PAI

a) Praktik Berjilbab Mahasiswi PAI

Dimensi selanjutnya dalam penilaian perilaku keagamaan mahasiswi yaitu praktik berjilbab mahasiswi. Keyakinan dan pengetahuan dalam beragama yang dianut mahasiswi akan mendorong penampilannya untuk berperilaku sesuai dengan ajaran agama yang dianutnya. Ekspresi keberagamaan mahasiswi diukur atau ditampilkan dalam sebuah berpakaian yaitu berjilbab. Tetapi tidak semua gaya berjilbab yang ditampilkan mahasiswi itu mencerminkan atau menunjukkan kondisi kehidupan agama masing-masing secara utuh.

Ekspresi keagamaan mahasiswi dalam berjilbab tidak hanya sekedar dari penampilan fisiknya saja yang terbalut oleh kain panjang, namun juga pada aktivitas yang ghaib seperti kekhusyukan dalam beribadah, namun peneliti tidak menganalisis perihal aktivitas peribadatan mereka secara menyeluruh, peneliti hanya membahas mengenai konsep jilbab mereka terhadap perilaku keagamaan mereka sesuai dengan fokus penelitian ini.

Praktik berjilbab mahasiswi yang penulis temukan dari hasil wawancara ada dua kategori, yaitu: 
(1) Praktik Jilbab Sebagai Kebiasaan

Praktik jilbab di kalangan mahasiswi tidak serta merta karena mereka sudah memahami perintah berjilbab dengan baik. Pandangan ini tidak muncul dengan sendirinya, melainkan berproses dari tahap awal. Berawal dari suatu peraturan yang diwajibkan oleh pihak sekolah, mereka mulai mengenal jilbab dengan baik, baik dari hasil peniruan daripada guru agamanya atau dari melihat hal lain yang mendorongnya bahwa jilbab itu baik, meskipun hanya digunakan sebatas pakaian formalitas.

Sesuai dengan perkembangan usia seseorang, maka tingkat kedewasaan juga akan mengikutinya. Demikianlah yang terjadi pada pertumbuhan dan perkembangan jiwa dan pemikiran mahasiswi. Melalui proses pembiasaan, mereka mulai memahami dan menyadari tentang makna jilbab yang sesungguhnya. Kebiasaan adalah suatu hal yang memberikan sifat dalam pikiran, keyakinan, keinginan dan percakapan; kemudian setelah seorang mahasiswi berada pada tahap dan sifat kebiasaan ini, maka mahasiswi tersebut akan terus mengulangnya karena timbulnya rasa suka berupa kenyamanan dan kesenangan terhadap apa yang sudah dilakukannya tersebut, yaitu menutup aurat dengan jilbab.

(2) Praktik Jilbab Sebagai Aktualisasi Syari'at

Menggunakan jilbab merupakan salah satu wujud menjalankan perintah kewajiban Tuhan. Pandangan ini di kalangan Mahasiswi PAI sebagai bentuk dari kesadaran dalam menjalankan ajaran agamanya. Sebagaimana dimensi pengetahuan keagamaan mahasiswi di atas, pada praktik ini mereka sudah berada pada taraf pemikiran yang sudah lebih maju dari praktik sebelumnya, yakni karena faktor kebiasaan. Pada tahap ini, mereka sudah sedikit banyak mengetahui 
dengan baik landasan-landasan ayat al-Qur"an perihal kewajiban berjilbab. ${ }^{15}$

Dengan senantiasa menggunakan jilbab, maka seorang wanita akan merasa lebih terjaga dan aman dari tingkah laku lawan jenis yang usil. Di samping merasa aman, ia juga akan merasakan nyaman dengan memakai jilbab dalam kesehariannya. Melalui pemakaian jilbab berarti seorang wanita muslimah ikut serta memelihara diri dari hal-hal yang menjerumuskan ke neraka, sebagaimana diketahui, bahwa mengumbar-umbar aurat adalah termasuk perbuatan dosa.

Hal ini sesuai dengan yang peneliti temui tentang praktik mereka menggunakan jilbab. Seiring dengan produksi jilbab secara besar-besaran yang melahirkan beragam mode, mereka menggunakan jilbab dengan berbagai macam mode sesuai dengan yang tengah berkembang saat ini di pergaulan anak muda. Mode jilbab yang mereka pakai dengan ciri khas dan istilah yang unik, seperti model kerudung Turki, dengan mode segi empat dengan motif yang relatif rame, berbunga-bunga, dengan warna-warna yang lebih mencolok, dengan pemakaian yang agak sederhana dan simple, cukup sedikit diputar ke belakang dan menutupi dada. Pashmina classic (model selendang panjang), dengan motif yang beragam, mulai dari bunga-bunga, kotak-kotak, dengan warna yang beragam serta mencolok, dan kombinasi warna dalam satu bentuk cara pemakaian jenis jilbab satu ini relatif lebih rumit dan ribet, karena bentuknya yang persegi panjang, yang berbeda dengan jenis jilbab lainnya. Model jilbab/kerudung scrafft (London styles), jilbab Syria, jilbab segi empat katun Paris-payet dan tanpa payet yang bahannya tipis, ringan dan lebih lentur, sehingga mudah untuk dibentuk, dililitkan ke samping kanan dan kiri dan ke atas kepala. Jilbab segi empat dengan bahan

15 Yusron Rozak, dkk. Pendidikan Agama, (Jakarta: Uhamka Press, 2001), h. 
yang sama dengan katun Paris dan diberi bordir dan jilbab segi empat yang berbahan tebal, tidak nerawang dan panjang ke bawah, biasanya hanya memiliki warna polos tanpa ada motif-motifnya

\section{b) Dimensi Pengalaman atau Penghayatan}

Dimensi ini berkaitan dengan pengalaman keagamaan, perasaan-perasaan, persepsi-persepsi, dan sensasi-sensasi yang dialami seorang mahasiswi selama berjilbab, baik karena faktor kebiasaan maupun pemahaman syariat. Dimensi pengalaman atau penghayatan ini dimensi yang menyertai keyakinan, pengamalan atau peribadatan. Dimensi penghayatan menunjuk kepada seberapa jauh tingkat mahasiswi dalam merasakan dan mengalami perasaanperasaan serta pengalaman-pengalaman religius selama menggunakan jilbab.

Dalam keberislaman, meyakini dan menghayati kebenaran, kebajikan, keindahan, keadilan, keimanan, dan nilai-nilai lain yang dianggap berharga ini terwujud ketika sudah memiliki perasaan dekat/akrab dengan Allah, perasaan doa-doanya sering terkabul, perasaan tenteram bahagia karena menuhankan Allah, perasaan bertawakkal (pasrah diri secara positif) kepada Allah, perasaan khusuk ketika melaksanakan shalat atau berdoa, perasaan tergetar ketika mendengar adzan atau ayat al-Qur'an, perasaan bersyukur kepada Allah, perasaan mendapat peringatan atau pertolongan dari Allah. ${ }^{16}$ Perasaan-perasaan seperti ini dapat dialami oleh seorang mahasiswi ketika mereka sudah benar-benar yakin dan tawakkal terhadap semua yang sudah diwajibkan yaitu menutup auratnya dengan jilbab.

Berdasarkan penuturan dari beberapa mahasiswi di atas, dapat dilihat bahwa mereka merasakan ketenangan,

16 Maragustam, Filsafat Pendidikan Islam: Menuju Pembentukan Karakter Menghadapi Arus Global, (Yogyakarta: Kurnia Kalam Semesta, 2014), h. 276 
keamanan dan ketenteraman dalam jiwanya. Mereka semua berada pada kondisi yang sehat mental jasmani dan rohaninya seperti yang penulis amati secara langsung dengan mereka. Pelaksanaan ibadah yang dilakukan secara rutin seperti, shalat, puasa, berbuat baik kepada sesama teman, zikir dan dilengkapi dengan berjilbab ikut berpengaruh dalam menanamkan keluhuran budi yang pada puncaknya akan menimbulkan rasa sukses sebagai pengabdi Tuhan yang setia. Peribadatan yang dilakukan setidak-tidaknya akan memberi rasa bahwa hidup menjadi lebih bermakna.

c) Dimensi Pengamalan atau Konsekuensi

Konsekuensi komitmen agama berlainan dari ke-empat dimensi di atas. Dimensi ini mengacu pada identifikasi akibatakibat keyakinan keagamaan, praktik, pengalaman, dan pengetahuan mahasiswi dari hari ke hari. Dimensi pengamalan atau akhlak menunjuk pada seberapa tingkatan mahasiswi berperilaku dimotivasi oleh ajaran-ajaran Islam, yaitu bagaimana individu berelasi dengan dunianya, terutama dengan manusia lain.

Dalam dimensi ini meliputi kemampuan mahasiswi dalam menyelaraskan antara jilbab yang digunakan terhadap perilaku keagamaannya. Sebagai konsekuensi dari keyakinannya tentang anjuran perintah jilbab dalam Islam, pengetahuan agamanya, praktiknya dan penghayatannya, sebagai calon guru Agama Islam mereka sudah menanam sikap dan sifat terpuji yang selayaknya dimiliki oleh seorang guru. Pengaruh jilbab secara psikologis ini dapat dilihat dari aspek kepribadian dan kemampuan bersosialisasi mahasiswi terhadap dunia luarnya. Hal ini seperti yang penulis amati ketika melakukan penulisan, baik di lingkungan kampus maupun luar kampus.

Penjelasan detail mengenai pengaruh tersebut adalah sebagai berikut: 
a) Kompetensi Kepribadian

Kepribadian guru merupakan suatu masalah yang abstrak yang hanya dapat dilihat melalui penampilan, tindakan, ucapan, serta cara berpakaiannya. Jilbab yang dipakai oleh mahasiswi PAI ini mampu memberikan dorongan secara psikologis bagi diri mereka untuk berbuat lebih baik. Kepribadian dan kemampuan mereka dalam bersosialisasi sudah baik, seperti yang penulis temui apa adanya di lokasi lapangan, baik di lingkungan kampus maupun luar kampus. Di samping belajar di kelas, mereka juga kerap mengikuti kegiatan keagamaan, seperti bedah buku Islami di GOR UNY, workshop, belajar tilawah di organisasi al-Mizan, dan aktif menghadiri kajian keIslaman. Mereka juga memiliki kemandirian untuk membantu meringankan beban orangtuanya, seperti kerja sampingan sebagai pramusaji untuk menambah uang saku, mengajar Les privat anak-anak, mengajar Iqra di sekolah, penulis buku, dan lain-lain.

Dapat disimpulkan dari data wawancara yang sudah peneliti lakukan, bahwa kepribadian seorang guru agama dipengaruhi oleh jilbab. Jilbab dalam arti bagaimana kekonsistenan seorang guru dalam mengenakan jilbab, bagaimana jilbab mengatur ucapan dan tindakan yang muncul dari dalam diri seorang guru ketika di dalam kelas dan luar kelas, dan bagaimana peran jilbab mempengaruhi seorang guru untuk selalu mendekatkan diri kepada Allah SWT. Inilah yang peneliti dapatkan juga ketika meneliti tentang konsep jilbab mahasiswi PAI sebagai calon guru agama Islam.

b) Kompetensi Sosial

Melihat perkembangan derasnya arus globalisasi saat ini, memacu semangat mahasiswi untuk memiliki ideide dalam mengajarkan ilmu agama kepada peserta didik 
agar mudah diterima oleh mereka. Ilmu agama yang seringkali diajarkan oleh anak selama ini cenderung monoton berkutat dan stagnan pada metode ceramah, sehingga anak-anak mudah merasa bosan dan kurang tertarik kepada pelajaran agama, khususnya dalam mengajari anak-anak didik untuk menutup aurat. Berdasarkan pengalaman yang sudah mereka alami, mereka berinisiatif untuk mengajarkan perintah menutup aurat dengan ide dan gaya yang baru.

Selain sebagai seseorang yang bertugas melakukan transfer of knowledge, guru juga sebagai seorang motivator dan fasilitator bagi proses belajar peserta didiknya. Seorang motivator adalah seseorang yang mampu memberikan motivasi dan semangat kepada peserta didik. ${ }^{17}$ Dilihat dari ide kreatifnya, mahasiswi tersebut sudah memahami dengan baik bagaimana kelak mereka akan mengajarkan ilmu agama kepada peserta didiknya. Sifat sebagai seorang pendidik sudah mereka miliki, yakni memiliki sikap yang tanggap dan responsif terhadap berbagai kondisi dan perkembangan dunia, yang dapat mempengaruhi jiwa, keyakinan dan pola pikir peserta didik. ${ }^{18}$

Mahasiswi membekali kemampuannya dengan cara berinteraksi, berkomunikasi dengan baik kepada keluarga, teman, dan membiasakan dirinya untuk dapat berinteraksi dengan lingkungan sosial yang berada di sekitarnya. Kegiatan yang diwadahi oleh pihak kampus memberikan banyak manfaat terhadap pola pikir dan perilaku bagi mahasiswi. Adapun organisasi tersebut seperti Tarbiyah News, Al-Mizan, LDK, KAMMI dan organisasi di luar

17 Uzer Usman, Menjadi Guru Profesional, (Bandung: PT Remaja Rosdakarya, 1992), h. 1

18 Syamsu Yusuf \& Nani Sugandhi, Perkembangan Peserta Didik, (Jakarta: Rajawali Press, cet-3, 2012), h. 139 
kampus lainnya, seperti karang taruna muda mudi, mengajar TPA dan lain-lain. Melalui acara sosial yang biasanya diadakan, seperti silaturahmi ke panti asuhan melatih pribadi mereka untuk mampu berkomunikasi dengan baik.

Dengan memiliki akhlak yang baik, dapat memudahkan sabagai seorang guru agama dalam mensosialisasikan ajaran Islam. Karakter terpuji yang sudah menjelma dalam diri seseorang akan terjadi secara spontanitas tanpa ada pemikiran panjang terlebih dahulu. Peserta didik akan merasa lebih yakin jika guru yang mengajarkannya berperilaku sesuai dengan apa yang disampaikannya. Hemat peneliti, guru yang ideal dan layak menjadi panutan adalah guru yang mampu menyelaraskan antara perkataan dengan perbuatannya secara langsung.

Dalam tahap penyelarasan tersebut, maka di butuhkan suatu proses bagi seorang guru untuk mensinkronkan kedua aspek tersebut, seperti menggali lebih dalam lagi belajar agama dan ilmu-ilmu sosial lainnya. Ketika seseorang memiliki berbagai multidisiplin ilmu pengetahuan, mereka cenderung lebih bersifat inklusif dengan tidak fanatik terhadap satu disiplin ilmu saja. Interaksi dan integrasi keilmuan yang lebih intens dan lebih padu antara "ilmu-ilmu agama" dengan "ilmu-ilmu umum", termasuk yang berkaitan dengan sains-teknologi akan menghasilkan dampak positif bagi kemajuan Pendidikan Agama Islam.

\section{Kesimpulan}

Konsep pemahaman tentang jilbab menurut Mahasiswi PAI Jurusan Fakultas Tarbiyah dan Ilmu Keguruan UIN Sunan Kalijaga Yogyakarta Angkatan 2013 sebagai calon guru agama tidak hanya memiliki konsep tunggal, terlebih jika dikaitkan dengan budaya pop (pop culture) saat ini, di antaranya: (1) Jilbab sebagai kewajiban Islam, 
(2) Jilbab sebagai identitas muslimah, (3) Jilbab sebagai motivasi pembentuk karakter, (4) Jilbab sebagai pelindung, (5) Jilbab sebagai bentuk penghormatan wanita, dan (6) Jilbab sebagai gaya hidup wanita muslimah.

Pengaruh konsep jilbab Mahasiswi PAI sebagai calon guru PAI terhadap perilaku keagamaannya dapat dilihat dari dua kompetensi, yakni dari kepribadian dan sosial. Kompetensi kepribadiannya adalah kreatif dan inovatif, dewasa, sopan dalam bertutur kata dan bertindak. Adapun dari kompetensi sosialnya adalah kemampuan mereka dalam berinteraksi dan bersosialisasi dengan baik terhadap orang-orang di sekitarnya.[]

\section{Daftar Pustaka}

Arifin, Bambang Syamsul, Psikologi Agama, Bandung: Pustaka Setia, 2015

Cole, Luella, Psychology of Adolescence. Holt Rinebart and Winston,(New York, 1953), dikutip dari buku Hanna Bastaman, Integrasi Psikologi dengan Islam: Menuju Psikologi Islami, Yogyakarta: Pustaka Pelajar, 1997

Daradjat, Zakiah, Pendidikan dan Kesehatan Mental, Jakarta: Bulan Bintang, 1976

Daud Fathonah K., "Jilbab, Hijab dan Aurat Perempuan (Antara Tafsir Klasik, Tafsir Kontemporer dan Pandangan Muslim Feminis)" Jurnal Studi KeIslaman, Volume 3, Nomor 1, Maret 2013.

Djamaludin Ancok, Fuat Nashori Suroso, Psikologi Islam, Jakarta: Pustaka Pelajar 2011

http://akhwat.beritaislamterbaru.org/2016/01/ketika-islamberkuasa-cadar-justru.html diakses pada hari Kamis, 26 Mei 2016 pukul 05.17

http://www.kompasiana.com/kompasiana/jilboobs-antara metamorfosis-esensi-jilbab-fenomena-tapi-bukan-tren-fashion muslim_54f5d9f0a33311424f8b472e diakses pada hari Rabu, tanggal 25 Mei 2016 pukul 05.25 
Maragustam, Filsafat Pendidikan Islam: Menuju Pembentukan Karakter Menghadapi Arus Global, Yogyakarta: Kurnia Kalam Semesta, 2014

Merdeka.com. Diakses pada hari Selasa, tanggal 24 Mei 2016 pukul 13.00.

Musaddad, Anwar "Hubungan antara Jilbab dengan Perilaku Islami", Jurusan Komunikasi dan Penyiaran Islam Fakultas Dakwah dan Komunikasi Universitas Islam Negeri Hidayatullah, Jakarta. 2008

Shahab, Husein, Hijab menurut al-Qur'an dan al-Sunah: Pandangan Muthahhari dan al-Maududi, Bandung: Mizan, 2013

Shihab, M. Quraish, Jilbab, Pakaian Wanita Muslimah: Pandangan Ulama Masa lalu dan cendekiawan kontemporer, Jakarta:Lentera Hati, 2004

Syamsu Yusuf \& Nani Sugandhi, Perkembangan Peserta Didik, Jakarta: Rajawali Press, cet-3, 2012

Usman Uzer, Menjadi Guru Profesional, Bandung: PT Remaja Rosdakarya, 1992

W. Allport, Gordon, The Individual and His Religion, The Macmillan Company; 1962. 32-36. dikutip dari buku Hanna Bastaman, Integrasi Psikologi dengan Islam: Menuju Psikologi Islami, Yogyakarta: Pustaka Pelajar, 1997

Yusron Rozak, dkk. Pendidikan Agama, Jakarta: Uhamka Press, 2001 